\title{
Future challenges of representing land-processes in studies on land-atmosphere interactions
}

\author{
A. Arneth ${ }^{1}$, L. Mercado ${ }^{2,3}$, J. Kattge ${ }^{4}$, and B. B. B. Booth ${ }^{5}$ \\ ${ }^{1}$ Karlsruhe Institute of Technology, Institute of Meteorology and Climate Research/Atmospheric Environmental Research \\ (IMK-IFU), Garmisch-Partenkirchen, Germany \\ ${ }^{2}$ University of Exeter, Geography, College of Life and Environmental Sciences, Exeter, EX4 4RJ, UK \\ ${ }^{3}$ Centre for Ecology and Hydrology, Wallingford, OX10 8ER, UK \\ ${ }^{4}$ Max Planck Institute for Biogeochemistry, Jena, Germany \\ ${ }^{5}$ Met Office Hadley Centre, FitzRoy Road, Exeter, EX1 3PB, UK
}

Correspondence to: A. Arneth (almut.arneth@nateko.lu.se)

Received: 11 February 2012 - Published in Biogeosciences Discuss.: 21 March 2012

Revised: 28 July 2012 - Accepted: 5 August 2012 - Published: 7 September 2012

\begin{abstract}
Over recent years, it has become increasingly apparent that climate change and air pollution need to be considered jointly for improved attribution and projections of human-caused changes in the Earth system. Exchange processes at the land surface come into play in this context, because many compounds that either act as greenhouse gases, as pollutant precursors, or both, have not only anthropogenic but also terrestrial sources and sinks. And since the fluxes of multiple gases and particulate matter between the terrestrial biota and the atmosphere are directly or indirectly coupled to vegetation and soil carbon, nutrient and water balances, quantification of their geographic patterns or changes over time requires due consideration of the underlying biological processes. In this review we highlight a number of critical aspects and recent progress in this respect, identifying in particular a number of areas where studies have shown that accounting for ecological process understanding can alter global model projections of land-atmosphere interactions substantially. Specifically, this concerns the improved quantification of uncertainties and dynamic system responses, including acclimation, and the incorporation of exchange processes that so far have been missing from global models even though they are proposed to be of relevance for our understanding of terrestrial biota-climate feedbacks. Progress has also been made regarding studies on the impacts of land use/land cover change on climate change, but the absence of a mechanistically based representation of human responseprocesses in ecosystem models that are coupled to climate
\end{abstract}

models limits our ability to analyse how climate change or air pollution in turn might affect human land use. A more integrated perspective is necessary and should become an active area of research that bridges the socio-economic and biophysical communities.

\section{Some fundamental aspects of land-atmosphere interactions research}

Over the last decades, research on the transport and transformations that take place at the interface between the land surface and the atmosphere focussed strongly on the attribution and projection of climate change. Briefly, a forcing $(\Delta F)$ through a change in the atmospheric concentration $(\Delta C)$ of long-lived greenhouse gases (LL-GHG) yields a change in temperature $(\Delta T)$, of a magnitude that depends on a proportionality factor $\left(\lambda_{1}\right.$; Fig. 1, adopted from Raes et al., 2010). This change in $T$ over time can be summarised by the Earth's energy balance equation in the short- and longwave spectra (Fig. 1):

$\frac{c_{\mathrm{h}} \mathrm{d} T}{\mathrm{~d} t}=\frac{S_{\mathrm{c}}}{4}(1-\alpha(T, C))-\varepsilon(T, C) \sigma T^{4} ;$

$\Delta T=\lambda_{1} \Delta F_{\mathrm{LL}-\mathrm{GHG}}$

where $t$ is unit time, $c_{\mathrm{h}}$ heat capacity, $S_{\mathrm{c}}$ solar constant, $\alpha$ albedo, $\varepsilon$ emissivity in the long-wave spectra, and $\sigma$ the Stefan-Boltzmann constant. 


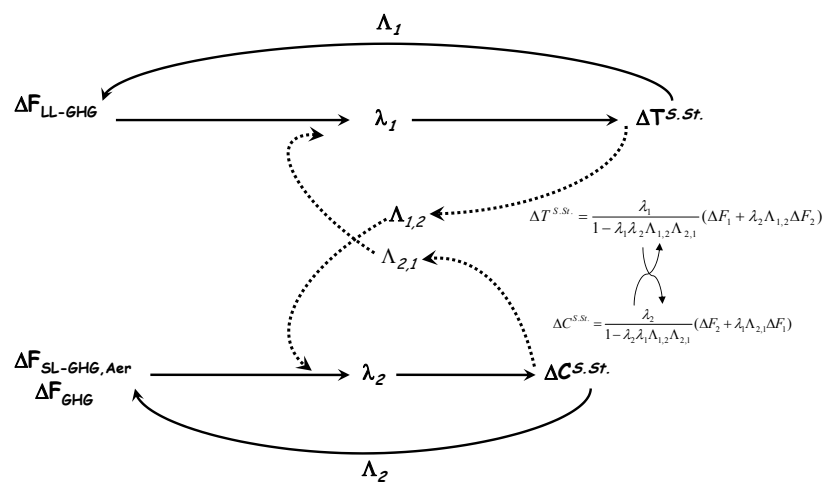

Fig. 1. Changes in forcing $(\Delta F)$ yield a system response $(\Delta T(T$ : temperature), $\Delta C$ (C: atmospheric concentration)) depending on its sensitivity $(\lambda)$ to $\Delta F$. Feedbacks $(\Lambda)$ may dampen or amplify the original forcing. " 1 " denotes processes relevant to the climate, "2" those to the pollution-chemistry system. GHG: greenhouse gas, either long-lived (LL) or short-lived (SL). Aer: aerosol particles. S.St.: steady state. Forcings are exerted by anthropogenic, ocean and terrestrial processes. Since processes in the physical climate system and those in the pollution/atmospheric concentration system do not operate independently from each other, assessment of proportionality and feedback factors $(\lambda, \Lambda)$ needs to account for both. The figure is adopted from Raes et al. (2010).

In addition to affecting burdens of long-lived GHG, emissions from, and uptake of, substances by the terrestrial biota play also a fundamental role regarding atmospherically short-lived substances and air pollutants like ozone or particulate matter. From a pollution point of view, in comparison to the physical climate system, a change in short-lived GHG and aerosols emissions yields a change in atmospheric concentrations, connected again by a proportionality factor $\left(\lambda_{2}\right)$. The magnitude of the changes in concentration can be expressed, in essence, by the dynamics of surface emissions, deposition, and reactions in the atmosphere (Fig. 1):

$\frac{\mathrm{d} C}{\mathrm{~d} t}=\left(E(T, C)-D(T, C)+R_{\mathrm{xn}}(T, C)\right) ;$

$\Delta C=\lambda_{2} \Delta F_{\mathrm{SL}}$ or LL-GHG, Aer

with $E$ emission, $D$ deposition/removal rates, and $R_{x n}$ netreaction in the atmosphere in case of reactive substances. In the physical climate system, as well as from the atmospheric chemistry and air quality perspective, an increasing number of feedbacks (denoted by " $\Lambda$ " in Fig. 1) are being identified that either attenuate or intensify the original forcings substantially (Raes et al., 2010). Furthermore, climaterelevant and pollution-relevant processes cannot be treated separately. Climate change affects air chemistry, while many pollutants tend to be also strong climate forcers (Dentener et al., 2006b). The quantification of the system's sensitivities $\left(\lambda_{1}, \lambda_{2}\right)$ to a forcing, and the manifold feedbacks $\left(\Lambda_{1}\right.$, $\Lambda_{2}$ ) that modify the forcing-change relationships, requires to treat $\lambda$ and $\Lambda$ not as independent entities but to explicitly ac- knowledge their influence on each other (Fig. 1; for details see Raes et al., 2010).

The impact of anthropogenic emissions on atmospheric burdens of long-lived GHG and short-lived GHG and particles is strongly modified by a number of ocean and land processes. The terrestrial biota and physical climate system are linked via emission and/or uptake of GHG like $\mathrm{CO}_{2}$, $\mathrm{H}_{2} \mathrm{O}, \mathrm{CH}_{4}$ or $\mathrm{N}_{2} \mathrm{O}$ (Arneth et al., 2010a). Human-caused air pollution and pollution-climate interactions are further affected by (i) emissions of biogenic volatile organic compounds (BVOCs) and nitrogen oxides $\left(\mathrm{NO}_{\mathrm{x}}\right)$ as these act as precursors for tropospheric $\mathrm{O}_{3}$ and secondary organic aerosol (SOA), (ii) by the uptake of $\mathrm{O}_{3}$ or $\mathrm{N}$-compounds through vegetation and soils, and (iii) by emissions from wildfires. Incidentally, feedback loops with contribution of the terrestrial biota that operate along the $\Delta F \rightarrow \Delta C \rightarrow \Delta F$ pathway are not exclusive to reactive, short-lived substances. The atmospheric burden of $\mathrm{CO}_{2}$, a long-lived GHG, affects its own atmospheric levels by feedbacks on plant photosynthesis (Fig. 1).

Various cooling and warming feedbacks associated with terrestrial biogeochemical cycle response to warmer temperatures and enhanced atmospheric $\mathrm{CO}_{2}$ concentration have recently been estimated to add up to around $\pm 0.8 \mathrm{~W} \mathrm{~m}^{-2} \mathrm{~K}^{-1}$ (Arneth et al., 2010a), excluding feedback estimates that were calculated by carbon-cycle-only models that in some cases considerably exceeded this range (Friedlingstein et al., 2006). Today, these C-only model experiments can be considered as being somewhat outdated, as an increasing number of studies that account for carbon-nitrogen interactions have shown a greatly altered response, in particular a substantially lower cooling feedback from $\mathrm{CO}_{2}$-fertilisation when $\mathrm{N}$-limitation is included (see Arneth et al., 2010a, and references therein). This limitation effect is only partially compensated for by enhanced $\mathrm{N}$-supply to vegetation from stimulated soil decomposition and $\mathrm{N}$-mineralisation in a warmer climate.

The terrestrial biogeochemistry feedbacks are of similar magnitude to those in the physical climate system (Soden and Held, 2006). This, taken together with the large uncertainties of individual feedback estimates and the scarcity of suitable simulation experiments (Arneth et al., 2010a), provides the principal incentive to improve our understanding of the underlying processes and their representation in global models of the Earth system. In what follows, we will highlight a number of critical points in this regard, being not so much concerned with magnitudes of feedbacks per se but with (i) advancements in quantifying uncertainties and confronting models with observations in a more systematic way; (ii) recent improvements regarding the representation of biota-atmosphere-climate interactions in global analyses; and (iii) the necessity to examine not only climate change but also land use and land cover change when studying landatmosphere interactions, especially those related to biogeochemical cycles on global scale. 


\section{Quantification of uncertainties and dynamic system responses}

When exposed to different growth environments, either in controlled experiments or as part of natural weather fluctuations, some plant species will rapidly acclimate their response patterns. This acclimation capacity is reflected for instance in altered photosynthesis and respiration rates, water use efficiency or above-to-belowground carbon allocation (Atkin and Tjoelker, 2003; Lloyd et al., 2002; Arneth et al., 2006; Gunderson et al., 2010; Hikosaka et al., 2006; Kozlowski and Pallardy, 2002). In global terrestrial models, however, equations for process-responses to changing environment and parameters used in these equations are typically set to be constant, at least within the same vegetation functional units. This approach reflects neither the large speciesto-species variation that occurs in nature nor the capacity for a plastic acclimation response. It also ignores the variability and uncertainties in the observations that underlie parameterization of model algorithms.

Applying a single emissions scenario (IS92a) and comparing effects of associated climate change simulated by five different general circulation models (GCMs) on the same land surface dynamic global vegetation model (LPJ) resulted in a change of total terrestrial carbon storage from present day to the end of the 21 st century of around -100 to $+200 \mathrm{PgC}$ (Schaphoff et al., 2006). In a contrasting experiment, using climate change projections from one GCM (HadCM2 with IS92a) but changing the key sensitive parameters in LPJ assuming for each a uniform probability density function around a pre-defined range, Zaehle et al. 2005) found a consistent land sink over the 21 st century, but weakening towards the end of the simulation period when net land atmosphere fluxes ranged between -1.8 to $-4.8 \mathrm{PgC} \mathrm{a}^{-1}$. Varying the model parameterisation in one dynamic global vegetation model (DGVM) resulted in late 20th to 21 st century changes in vegetation and carbon pools that were quite similar to the range found between different DGVMS, of approximately a factor of two for vegetation pools, and a factor of six for soil pools (Cramer et al., 2001; Zaehle et al., 2005). The uncertainty that appears to be associated with choosing parameter values is also of a magnitude comparable to that found to be introduced by different climate projections (Schaphoff et al., 2006), with the added exception that Schaphoff et al., 2006 found not only a large variation but even a change in the sign of the response.

Recent work by Booth and colleagues (Booth et al., 2012) used uncertainty in the model parameters, of the DGVM component of HadCM3C, as a way to characterise uncertainty in key terrestrial processes in historical and future simulations of the coupled climate-carbon cycle system (Fig. 2). Here, too, using only a single emissions scenario (SRES A1B, with HadCM3C climate), the associated spread in calculated 2100 atmospheric $\mathrm{CO}_{2}$ burdens arising from the parameter variation itself was large, larger than across all

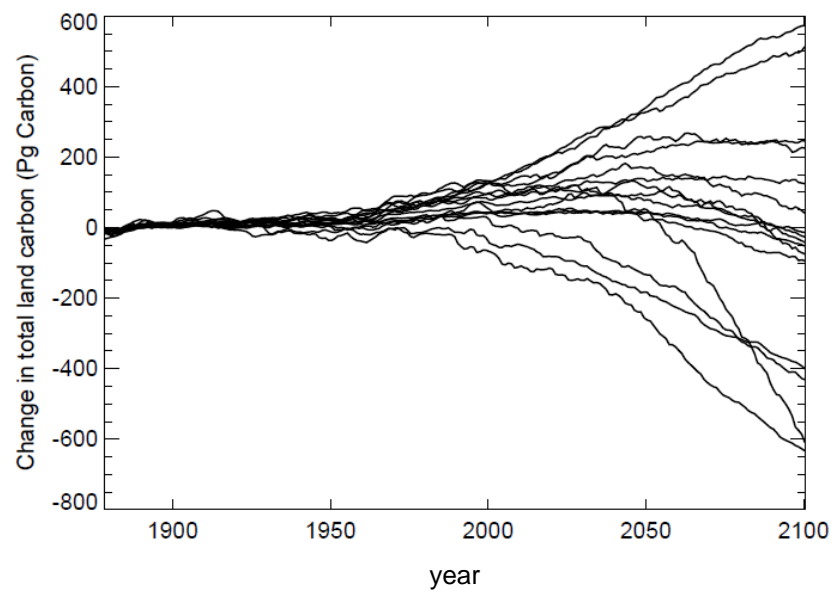

Fig. 2. Simulated change in terrestrial C-pools over the late 19th and 20th century, and until 2100, in 17 versions of HadCM3C, a fully coupled climate-carbon cycle model. Future projections are driven by a single emission scenario, SRES A1B. Spread between the land carbon responses illustrates uncertainty in the terrestrial response arising from perturbations, within plausible ranges, to six key parameters related to vegetation carbon and water balance using a design that minimises correlations between parameters (for details see Booth et al., 2012)

SRES scenarios (Booth et al., 2012). Moreover, the highest atmospheric $\mathrm{CO}_{2}$ concentrations exceeded concentrations from the highest SRES scenarios considerably (by about $100 \mathrm{ppm})$. In the analysis, parameters were sampled using a Latin hypercube design, which seeks to explicitly minimise correlations between parameters. Yet, with 6 parameters and 17 simulations (Fig. 2), some degree of correlation is inevitable, and, as discussed in more detail (Booth et al., 2001), it was thus only possible to tie model responses to parameters where only one or two parameters dominate. Among the six processes that were varied, the temperatureoptimum of photosynthesis emerged as one of the main uncertainties for the overall land-surface response (Fig. 2). In a future, warmer world without photosynthetic acclimation, optimum temperatures of photosynthesis, on the lower end of the explored temperature range, showed consistent global vegetation $\mathrm{C}$-uptake decline (driven largely by response in the tropical regions), leading to lower productivity, and to mortality. The uncertainty in future global temperature arising from the variable parameterisation of terrestrial C-cycle processes was of the same order as that associated with physical processes.

Systematic data mining and data assimilation into models can reduce uncertainties related to parameterisations considerably (Knorr and Kattge, 2005; Scholze et al., 2007; Ziehn et al., 2011). By giving more weight to simulations that show greater skill at representing observations, for instance plant trait data (TRY database; Kattge et al., 2011), Ziehn et al. (2011) assimilated observational data into a perturbed 

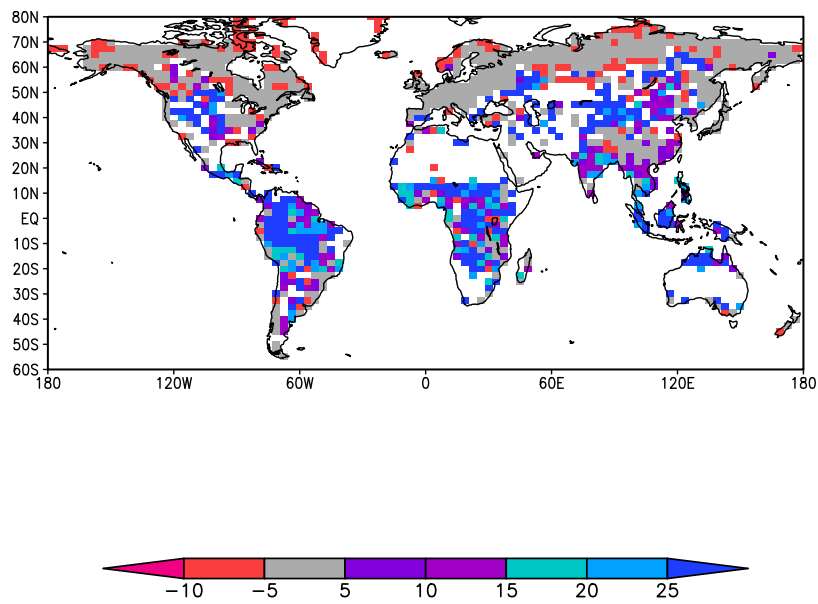

Fig. 3. Relative changes in gross primary productivity (GPP, expressed in \%) from simulations without to with acclimation of $V_{\mathrm{cmax}}$ and $J_{\max }$ at the end of the $21 \mathrm{st}$ century, estimated as (GPPacclim-GPPnon-acclim)*100/GPPnon_acclim (Mercado et al., unpublished). Results are equilibrium simulations with climate warming as $2{ }^{\circ} \mathrm{C}$ compared to present day, using a coupled IMOGEN-JULES set-up (Huntingford et al., 2010). Values below $-10 \%$ are excluded. Areas indicated in white colour are mostly dry and with low productivity. In addition, in some (productive) areas the model predicts a change in vegetation composition which complicates the analysis of acclimation effects. These were thus also excluded from plotting.

parameter exploration of terrestrial uncertainties. The model optimisation led to a much reduced uncertainty in global GPP simulations, both for the present day and for the future, and to a more realistic total simulated present-day GPP when compared to observation-based estimates. Akin to the Booth et al. (2012) study, the remaining uncertainty was strongly related to temperature acclimation responses, including that of photosynthesis. It seems clear from these emerging simulation exercises that the quantification of climate change risks to terrestrial ecosystems requires not only to take into consideration uncertainties in climate projections (Scholze et al., 2006) but also to acknowledge the possibility for dynamic adjustments in vegetation or soil process responses. In principle, algorithms used in terrestrial models could be adopted to describe dynamics of acclimation (Kattge and Knorr, 2007; Medlyn et al., 2002), for instance by modifying the entropy terms that describe the temperature response of photosynthetic electron transport rate and C-fixation reactions. But deficiencies in our understanding of the underlying processes and lack of suitable data have prevented a quantitative treatment of photosynthesis or respiration acclimation responses in simulation studies of global carbon cycle-climate interactions. In a first attempt to address acclimation phenomena, focusing on photosynthesis-temperature relations on the global scale, Mercado et al. (unpublished; Fig. 3) implemented the Kattge and Knorr (2007) temperature acclima- tion descriptions of maximum electron transport rate $\left(J_{\max }\right)$, and maximum rate of ribulose-1,5-bisphosphate carboxylation $\left(V_{\mathrm{cmax}}\right)$ into the JULES land surface model (Clark et al., 2011). JULES was run to equilibrium for a 2-degree future warming scenario, and associated elevated atmospheric $\mathrm{CO}_{2}$ levels of $407 \mathrm{ppmv}$, based on the Hadley Centre climate model (Huntingford et al., 2010). Preliminary results showed an increase in simulated annual gross primary productivity by up to $25 \%$ in the year 2100 , compared to simulations that do not allow for a plastic adjustment of photosynthesis to a changing growth environment.

In comparison to the generally fixed parameterisations describing the environmental response of plant carbon and water relationships, most models also assume a static allocation of the net assimilated carbon into above- and belowground compartments (Wolf et al., 2011) even though root-to-shoot ratios are known to vary plastically with light, water and nutrient supply (Litton et al., 2007; Kozlowski and Pallardy, 2002). The underlying theory of such a plastic response is of a carbon investment that allows for best capturing the most limiting resource. Only few of the state-of-the art models allow for a dynamic distribution of the assimilated carbon to above- and belowground growth in response to soil water and/or nutrient deficiencies (Scheiter and Higgins, 2009; Smith et al., 2001; Zaehle and Friend, 2010). The parameterization of these dynamics is highly uncertain since the mechanisms behind observed variable allocation patterns are not very well characterized beyond the conceptual level.

Not accounting for acclimation responses, either for fast gas-exchange or for slower growth-related processes in terrestrial models, can lead to questionable carbon fluxes, turnover times and pools, which will affect carbon cycle concentration and climate feedbacks (Fig. 1). Realistic representation of ecosystem ecological properties, like competition, response to disturbance or vegetation fractional cover, critically relies on representation of plasticity in carbon allocation and growth. Moreover, ecosystem responses to environmental changes might well be more resilient than expected when allowed to adjust flexibly. This includes stability through adjustment in species composition (see Kühn et al., 2008; Isbell et al., 2011; and references therein). Modelling species distributions on global scale clearly is not feasible, and DGVMs that represent vegetation by a limited number of plant functional types have not been designed to test ecosystem function in response to adjustment of species richness. What is more, DGVMs typically do not include processbased description of migration patterns of individual species. While the models have been shown to successfully reproduce past changes in larger vegetation units that can be inferred from pollen records (Miller et al., 2008; Kleinen et al., 2011), the assumption of mutually immediate distribution shifts in response to rapid future climate change remains unproven, with potentially large implications for transient simulations of terrestrial carbon and nitrogen balances (Solomon and Kirilenko, 1997; van Minnen et al., 2000; Higgins, 2009). 


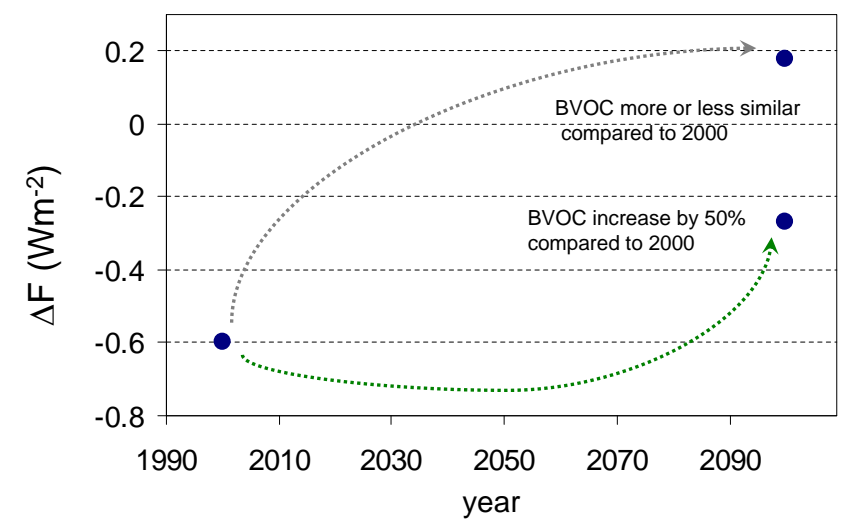

Fig. 4. Difference in (mean) total anthropogenic aerosol radiative forcing $\left(\mathrm{Wm}^{-2}\right)$ between simulations with and without accounting for effects of new particle formation $\left(-0.6 \mathrm{Wm}^{-2}\right.$ for presentday conditions). Simulations in 2100 reflect anthropogenic emission changes, with the additional effect of biogenic emissions (monoterpenes) being more or less unchanged compared to present day, and with an assumed increase of monoterpene emissions by $50 \%$. Figure is redrawn from Makkonen et al. (2012). Dotted lines do not represent modelled trajectories between present day and late $21 \mathrm{st}$ century.

Still, resolving canopy structural processes and individual establishment and mortality is feasible with some of today's state-of-the art models, and it has been shown that including such features aids analysis of diverse processes such as habitat diversity (Hickler et al., 2012), emissions of BVOC, or structural stability (Higgins and Scheiter, 2012). While approaches to address these aspects on global scale are still in their infancy, it seems advisable to advance the field in this direction, for an improved assessment of climate change impacts, and thus development of adaptation and mitigation strategies, and for the analysis of tipping points.

\section{Beyond the $\mathrm{CO}_{2}$-centric perspective: missing processes with large climate feedback potential}

Despite their potentially large impact on atmospheric composition and feedbacks to climate, a number of terrestrial biotaatmosphere exchange processes are incompletely quantified in today's global models (Arneth et al., 2010a). One of these is the emission of biogenic volatile organic carbon (BVOC) from vegetation that, directly or via atmospheric oxidation products, contributes to the formation and growth of secondary organic aerosol (Kulmala et al., 2004). To date, experimental and modelling work has concentrated on isoprene (I) and monoterpenes (MT), even though it is known that other BVOCs, especially the C-15 isoprenoids that form the group of sesquiterpenes, are also crucially relevant in that context (Bonn and Moortgat, 2003). In response to anthropogenic climate change, most models assume a strong increase in $I$ and MT emissions (Carslaw et al., 2010), chiefly because of the well-known stimulation of leaf emissions by increasing temperature (see Niinemets et al. (2010), and references therein). There are, however, considerable uncertainties when additional effects are considered, for instance a direct $\mathrm{CO}_{2}$-inhibition of leaf production of some $\mathrm{BVOC}$, like isoprene, or the additional effects of changes in canopy properties and species composition in response to climate change and atmospheric $\mathrm{CO}_{2}$-increases (Possell and Hewitt, 2010; Arneth et al., 2008; Arneth et al., 2007; Heald et al., 2009). In one model study, the competing direct and indirect effects that affect emissions on leaf as well as on entire canopy scale resulted in more or less no change of emissions or even small decline when applying a variety of future climate and $\mathrm{CO}_{2}$ scenarios (Arneth et al., 2007).

Attempts to date to quantify the direct climate effects of secondary organic aerosols in response to assumed increasing BVOC emissions over the 21 st century suggest a substantial cooling (up to $-24 \mathrm{~W} \mathrm{~m}^{-2}$; Carslaw et al., 2010) due to the SOA particles scattering and reflecting radiation. SOAs also act as cloud condensation nuclei with associated indirect climate effect asserted via cloud albedo and lifetime (Lohmann and Feichter, 2005). So far, climate models cannot account for the full chain of processes that includes emissions of particle precursors, particle nucleation, and subsequent growth, all taking place with different reaction rates and chemistry in pristine vs. polluted environments (Kulmala, 2003; Donahue et al., 2005; Ng et al., 2007). As a consequence, the full feedback loop from changing temperature and precipitation, affecting BVOC emissions, affecting SOA and climate in turn (Fig. 1) has not yet been addressed quantitatively (Arneth et al., 2010a). However, a recent study (Makkonen et al., 2012) showed that accounting for nucleation in an aerosol-climate model notably increased the number and concentration of cloud condensing nuclei $(\mathrm{CCN})$, yielding a near-doubled present-day cooling (total aerosol forcing from all particles, anthropogenic and biogenic) of about $-1.6 \mathrm{Wm}^{-2}$, compared to a forcing of around $-1 \mathrm{Wm}^{-2}$ when this process was disregarded. What is more, the assumed reduction in aerosol total forcing from the present day to the year 2100 was about twice as large when nucleation was considered, compared to excluding it. Although this change in forcing was mostly related to anthropogenic pollution control assumptions in the 21 st century scenario, especially the removal of sulphate as cooling aerosol precursors (Andreae et al., 2005), large uncertainties were identified with respect to changing biogenic emissions (Fig. 4). Impacts of pollution control on climate change are largely driven by reducing anthropogenic emissions, but interactions with biogenic emissions in response to climate change have the potential to offset some of the pollution control effects exemplifying the need to quantify feedbacks arising from climate change and air chemistry interactions (Makkonen et al., 2012; see also Fig. 1). 
Climate change effects on soil $\mathrm{N}_{2} \mathrm{O}$ emissions are a further example for an atmosphere-biota feedback for which, although established qualitatively, no quantitative assessment has been published yet as to its magnitude (Arneth et al., 2010a). Like all microbial activity, nitrification and denitrification are strongly stimulated by temperature and moisture but it is $\mathrm{N}$-addition from atmospheric deposition and fertilisation, rather than climate change directly, that acts as the chief anthropogenic driver of enhanced ecosystem emissions of $\mathrm{N}_{2} \mathrm{O}$, as recently confirmed in a meta-analysis of observations (Liu and Greaver, 2009, and references therein). Emissions of $\mathrm{N}_{2} \mathrm{O}$ respond also positively to $\mathrm{CO}_{2}$ fumigation albeit on a smaller scale (Van Groenigen et al., 2011), with an increase of around $20 \%$ on average, compared to the average 2 - to 3 -fold increase (maxima $>10$-fold) in the $\mathrm{N}$-addition experiments. Overall, the evidence obtained in laboratory and field trials indicates that the dynamics of terrestrial $\mathrm{N}_{2} \mathrm{O}$ emissions cannot be understood from examining effects of $\mathrm{N}$-deposition or climate effects in isolation, but require an integrated carbon-climate-vegetation-land use perspective.

Zaehle et al. (2011) simulated effects of land cover change, climate change, and changing atmospheric $\mathrm{CO}_{2}$ concentration on terrestrial $\mathrm{C}$ - and $\mathrm{N}$-fluxes, and compared these with effects of increasing $\mathrm{N}$-inputs from atmospheric $\mathrm{N}$ deposition and intensified fertilisation over about the last 150 years, using the $\mathrm{N}$-version of the model ORCHIDEE. When homing in on changes in global terrestrial C-fluxes, the opposing effects of land cover change and $\mathrm{CO}_{2}$ fertilisation dwarfed those of climate change and $\mathrm{N}$-fertilisation over the simulation period. However, when taking the increase in atmospheric $\mathrm{N}_{2} \mathrm{O}$ burden over the same period as metric, its trend as recorded in ice cores and by global flask sample networks could only be replicated with a simulated terrestrial biota that receives $\mathrm{N}$-input from deposition and fertilisation. The model results not only confirmed the substantial contribution from the terrestrial source to total atmospheric $\mathrm{N}_{2} \mathrm{O}$. When expressed as present-day radiative forcing, warming effects of the $\mathrm{N}_{2} \mathrm{O}$ emissions more than outweighed the cooling effects of carbon gain from the $\mathrm{N}$-fertilisation (Zaehle et al., 2011).

The results presented in Zaehle et al. (2011) can also be viewed more generally in light of the impacts of land use and management in the climate system. Although not explicitly targeting this debate, they underpin arguments for a cautious assessment of the net effects of the climate change mitigation potential of bioenergy plantations; the carbon gain needs to be assessed alongside other climatically relevant trace gases like $\mathrm{N}_{2} \mathrm{O}$ (Crutzen et al., 2008; Lisboa et al., 2011). Conversely, concluding that intensification of land use and management will consistently lead to enhanced $\mathrm{N}_{2} \mathrm{O}$ emissions would also seem oversimplified. $\mathrm{N}_{2} \mathrm{O}$ emissions are known to be highly heterogeneous in time and space, and production and efflux are governed by a multitude of factors. In grasslands in Inner Mongolia, about $70 \%$ of the total annual $\mathrm{N}_{2} \mathrm{O}$ budget was emitted over a period of few days only, in re-

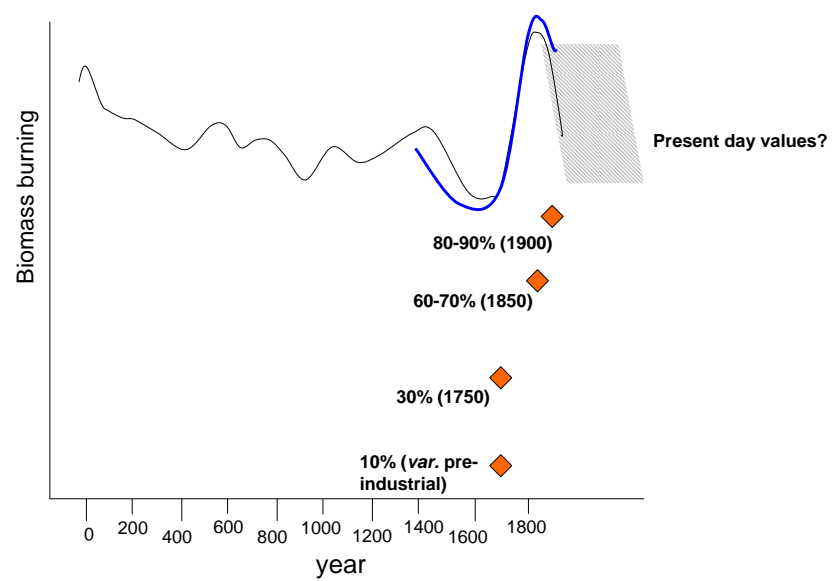

Fig. 5. Changes in global biomass burning over the last 2 millennia, derived from charcoal indices (black line; Marlon et al., 2008), and for the Southern Hemisphere over the last few centuries, derived from CO measurements in ice cores (blue line; Wang et al., 2010). Lines are redrawn from Prentice (2010), and changes are indicated as relative only, without scale. Diamonds indicate various assumptions about pre-industrial wildfire emissions with respect to present day (Ito et al., 2007; Lamarque et al., 2010; Mieville et al., 2010; Dentener et al., 2006a). Years in brackets are the years chosen for the base-line simulations. The " $10 \%$ " assumption has been used in a number of studies and for a number of different base-line years (var. pre-industrial). The grey shaded area indicates the uncertain pyrogenic emissions from the middle of the 20th to early 21 st century, which cannot be derived from ice core or sediment charcoal records.

sponse to freeze-thawing in spring - but this phenomenon occurred in a non-grazed, non-intensively used site (Wolf et al., 2010). The emission pulses disappeared at more intensely grazed study locations, where high livestock density and grazing reduced snow cover and isolation from cold winter air temperatures, which affected winter soil temperatures, water balance, and microbial biomass. Scaling these differences observed in grazed vs. non-grazed land to the area covered by cool temperate, semiarid grassland globally implies substantially lower total $\mathrm{N}_{2} \mathrm{O}$ emissions compared to previous methods (around $0.04 \mathrm{Tg} \mathrm{N} \mathrm{a}^{-1}$ vs. 0.07-0.12 $\mathrm{Tg} \mathrm{N} \mathrm{a}^{-1}$ ) that ignore grazing-induced reduction in $\mathrm{N}_{2} \mathrm{O}$ production (Wolf et al., 2010). While this represents a small contribution to the total estimate of terrestrial $\mathrm{N}_{2} \mathrm{O}$ fluxes of around 4-12 $\mathrm{Tg} \mathrm{N} \mathrm{a}^{-1}$ (Gruber and Galloway, 2008), it nonetheless calls attention to the complexity of the issues that still remain unresolved. The observed spatial and temporal heterogeneity seems much larger for emission fluxes of non- $\mathrm{CO}_{2}$ trace gases than for $\mathrm{CO}_{2}$; it is also frequently observed for $\mathrm{CH}_{4}$ emissions in wetlands (Wania et al., 2010) and difficult to resolve with today's global modelling approaches. It remains to be tested whether or not absence of small-scale heterogeneity introduces a systematic bias or diminishes in importance when calculations are done globally to derive annual budgets. 


\section{Beyond climate change}

The interactions of land use/land management change with global and regional $\mathrm{N}_{2} \mathrm{O}$ emissions provide already evidence to human activities affecting land-atmosphere interactions far beyond climate change alone (Levis, 2010). There are many other illustrative examples; biomass burning in wildfires is among the most compelling, as fires may be ignited, spread, as well as extinguished by either natural factors or humans. Recent fire models have attempted to include ignition or extinction effects (Pechony and Shindell, 2009; Thonicke et al., 2010). Compiling charcoal samples found in peatand sediment cores that cover approximately the last two millennia, Marlon et al. (2008) identified - on the continental to global scale - a steady decrease of burning parallel to a cooling trend to around 1650, followed by a steep increase in fire activity until ca. 1850-1900 (Fig. 5). For a timespan dating back a bit more than the last six centuries, this pattern was corroborated by analyses of $\mathrm{CO}$ in air trapped in ice cores (Wang et al., 2010). The strengthening of the fire regime in the late 17th century could be discussed in light of warming climate, but is probably most strongly associated with a rapidly expanding population and associated land clearance (Marlon et al., 2008; Pechony and Shindell, 2010). Upon peaking in the late 19th and early 20th century, wildfires declined rapidly as landscape fragmentation and active fire fighting prevented fire spread, and as unintentional ignition sources declined due to increasingly industrialised and urbanised lifestyles.

Fire links terrestrial and atmospheric processes in manifold ways. It is ubiquitous and intrinsic to terrestrial ecology, rejuvenating ecosystems and accelerating carbon turnover (Bond-Lamberty et al., 2007; Bowman et al., 2009; Hoffmann et al., 2003). Fire exclusion in experimental plots typically results in vegetation shifts towards denser, woody dominated types (Bond et al., 2005). Advanced terrestrial models can reproduce this effect (Bond et al., 2005; Scheiter and Higgins, 2009; Arneth et al., 2010b). In African savannas, globally amongst the most fire-prone biome, a sigmoidal decline in woody towards grass cover seen with decreasing mean annual precipitation was - in part - attributed to recurring disturbance, including disturbance by fires (Bucini and Hanan, 2007; Arneth et al., 2010b). Disturbances are argued to keep woody biomass below its climate optimum in mesic regions. One of the arguments for fire playing an important role in sustaining such patterns is that tree seedlings of low height are killed by fire; only those that grow tall enough to escape the flame height danger zone can develop into adult specimens (Higgins et al., 2000; Staver et al., 2011).

Beyond ecological implications, the proper representation of whether vegetation is dominated by trees, by grasses, or by a tree-grass mix will also affect important surface characteristics that are of relevance to regional climate: amongst others, short-wave albedo, evapotranspiration rates from soil and vegetation, canopy conductance, and Bowen ratio (Pit- man et al., 2011; Scheffer et al., 2005). Fire influences climate also by being a major source of atmospherically shortlived trace gases (especially ozone) and organic as well as black carbon aerosols (Janhäll et al., 2010; Langmann et al., 2009; see also Fig. 1). Assessments of the radiative forcing associated with these pyrogenic emissions have mostly assumed pre-industrial baseline fire emissions of around $10 \%$ compared to present (Ito et al., 2007). Clearly, these assumptions are not supported by the patterns recently inferred from charcoal and ice cores (Fig. 5; Marlon et al. 2008; Wang et al. 2010). Only some of the most recent studies have applied pre-industrial emission estimates up to around 30 to $60 \%$ or even $90 \%$ of present day (Fig 5; Dentener et al., 2006a; Ito et al., 2007; Lamarque et al., 2010; Mieville et al., 2010) to simulate effects on air quality. Effects on radiative forcing calculations arising from the evidently small differences between pre-industrial and present pyrogenic emissions await a more systematic analysis in coupled chemistry-climate models that account for climate change effects on fire regimes, and the related feedbacks from effects of pyrogenic emissions in the air chemistry system (Fig. 1). In one set of experiments, Ito et al. (2007) found that fire-related present-day $\mathrm{O}_{3}$ radiative forcing was reduced from $0.47 \mathrm{Wm}^{-2}$ in the " $10 \%$ case" to $0.4-0.42 \mathrm{Wm}^{-2}$ when pre-industrial biomass burning emissions were set to about $35-45 \%$ of present day.

As the relative importance of climate vs. human impact on fire regimes appears to undergo strong, and in some cases rapid changes, a better understanding of the drivers and interactions behind these patterns is necessary. The lack of representation of the dynamics of biomass burning realistically in advanced terrestrial models is an important impediment for assessing past, present and future interactions of changing fire regimes, terrestrial ecology, air quality and climate. However, even though the palaeo-records can inform simulation experiments with respect to plausible past scenarios, a substantial gap in our knowledge exists with respect to the changes in the global and continental fire regimes from perhaps around the middle of the 20th century to the present (Fig. 5). The sediment and ice-core records cannot cover the most recent past reliably, and existing satellite remote sensing information record does not have sufficient length to robustly infer recent trends or average fire patterns.

\section{Effects of land use/land cover change on climate change - and vice versa?}

Conversion of natural vegetation into agriculture and pastures, mostly by deforestation, has contributed since the $1960 \mathrm{~s}$ an estimated net release of annually $1.5-1.6 \mathrm{Pg} \mathrm{C} \mathrm{a}^{-1}$ into the atmosphere (Canadell et al., 2007), and an estimated accumulated total of $>150 \mathrm{PgC}$ since 1850 (Houghton, 2003). That way, anthropogenic land cover changes assert a substantial climate warming effect. But cropland and pastures also tend to have higher short-wave albedo compared to 
forests; the enhanced reflection of radiation asserts a regional cooling of the land surface (Betts, 2000, 2001). Regional climate effects of agricultural land also arise when evapotranspiration rates are being altered, for instance by shorter crop growing seasons compared to natural vegetation, by lower rooting depths or by the presence or absence of irrigation. In a recent simulation experiment (Arora and Montenegro, 2011), the biophysical and C-cycle climate effects of land use/land cover change were analysed side-by-side. Applying two rather theoretical scenarios of $100 \%$ and $50 \%$ afforestation by 2060 , the calculated change in surface temperature at the end of the 21 st century from the afforested area was a biogeochemical cooling across the globe caused by enhanced C-uptake in re-growing forests. However, the biophysical effects of forest regrowth deviated in boreal and temperate, and tropical environments. Surface cooling was simulated to follow afforestation in the tropics, where large evapotranspiration rates in forest exceeded effects of reduced albedo, whereas for the boreal and temperate regions evapotranspiration is limited by plant-available soil moisture and albedo-related effects dominated. Whether such regional patterns reflect a robust understanding of exchange processes in the physical land-climate system remains to be seen, since overall the simulated biophysical effects of land use change seem to diverge strongly between climate models. In a recent intercomparison (Pitman et al., 2009), all partaking models computed a significant physical impact of land use change over the regions this land use change took place, but the models disagreed on the direction of the change for a number of climate-relevant metrics, like latent heat fluxes. Diagnosing the causes for these discrepancies is hampered by the different ways land use and land cover changes were implemented in the models (de Noblet-Ducoudré et al., 2012). Moreover, the representation of important crop characteristics like crop phenology, effects of management practices and overall crop growth dynamics is still at the very beginning in terrestrial models (Arneth et al., 2010c) and it is presently absent from land surface schemes in global climate models.

Despite these large uncertainties, the climate modelling community agrees on human land use/cover changes substantially affecting climate change, regionally and globally. The question arises as to whether there exist feedbacks in this system such that climate change in turn affects human decision making and land use to a degree that it can be distinguished from other major driving forces such as population growth and economic development. One crucial aspect in this context is how climate change impacts yields and the technological capacity to combat these in regions of adverse effects. It seems plausible to hypothesise that some regions will benefit from climate change; for others it will be detrimental. (Easterling et al., 2007). A temperature increase by about $2{ }^{\circ} \mathrm{C}$ arguably can increase wheat and rice yields in the cool mid to high latitudes, while in the low latitudes yields may decline already at very moderate warming (Gornall et al., 2010). On global average, an overall decline in yields of major crops might be expected (Deryng et al., 2011) but adaptation of management practises like sowing or harvesting dates to a changing climate might aid to reduce losses (Gornall et al., 2010; Deryng et al., 2011). Here, too, the simulated potential to reduce adverse effects by such relatively simple and inexpensive management practices was smallest in regions that are already warm today (Gornall et al., 2010; Deryng et al., 2011). Incidentally, studies that seek to assess the interactions of climate change, yields and terrestrial biogeochemical cycles, with other important facets like increasing $\mathrm{CO}_{2}$, so far are rare and/or concentrate on regional rather than global scales (Mueller et al., 2010; Huang et al., 2009). Enhanced $\mathrm{CO}_{2}$ should at least be somewhat beneficial to $\mathrm{C} 3$ crops even though experimental evidence is conflicting (see Jaggard et al. (2010) and references therein). No published work to our knowledge has assessed crop yield and biogeochemical cycling response on global scale to increasing ozone levels, despite the ozone's known deleterious effects (Ashmore, 2005). Moreover, crop yields will be heavily influenced by climate extremes and weather variability, which requires more sophisticated model experiments that move beyond representing only the effects of climate trends (Trnka et al., 2011; Challinor, 2011).

Climate change can be expected to affect the type and aerial extent of some crops, directly (via yield) and indirectly (via indirect land use changes in response to climate mitigation strategies, like promotion of biofuels; Melillo et al. 2009). Future land use changes will arise under the premises that future climate change results in variable yields and yield losses that cannot be compensated for by improved technology, management of crop varieties, or management of farming systems, and that these effects together with competition for bioenergy put pressure on food prices. Quantification of feedbacks between socio-economic and biophysical/biogeochemical dynamics remains a challenge, while even the interactions between important environmental drivers and crop yields are poorly represented in terrestrial models (Rotter et al., 2011). Still, a more integrated perspective is necessary and should become an active area of research that bridges the socio-economic and biophysical communities (Hulme, 2011) to facilitate robust analysis of how people affect the global environment and to test for global effects of climate change mitigation and adaptation strategies (Rounsevell and Arneth, 2011).

\section{Conclusions}

To date, research on land-atmosphere interactions has concentrated strongly on impacts of climate change and feedbacks related to biophysical and carbon cycle responses. A number of studies have shown that improved representation of biological and ecological process understanding can alter model projections of land-atmosphere interactions substantially, with examples ranging from all aspects of 
carbon-nitrogen interactions, to considering $\mathrm{CO}_{2}$ effects in addition to climate change effects, to treating disturbance as well as acclimation responses to environmental changes. These improvements will not only affect the forcings and feedback parameters in the greenhouse gas - physical climate system, but also alter results in coupled chemistryclimate model experiments (see Fig. 1). It is therefore a chief challenge to understand these interactions, and to represent these in consistent modelling and observational frameworks. Moreover, while concentrating on temperature changes, we should not forget that the terrestrial biota also strongly responds to changing precipitation and soil moisture status, which also warrants a more explicit treatment in model analyses.

But how complex can and need terrestrial models be? We have shown here that convincing arguments can be found for an ever-increasing number of process representations in terrestrial models, but these examples clearly also demonstrate that quantitative understanding in many cases is incomplete. Models require empirical parameterisation on global scale and often are difficult to evaluate since observations on the appropriate scales are lacking. Where possible, data assimilation together with systematic analysis of uncertainties can aid to identify the most uncertain aspects and guide model development.

Acknowledgements. AA acknowledges support from Swedish Research Council Formas; this manuscript contributed also to EU FP7 IPs ECLAIRE (FP7-ENV-2011/282910), PEGASOS (FP7-ENV2010/265148), and EMBRACE (FP7-ENV-2011/282672). LM also acknowledges support from the EU FP7 project ECLAIRE. B. B. Ben Booth was supported by the Joint DECC/Defra Met Office Hadley Centre Climate Programme (GA01101).

Edited by: N. Saigusa

\section{References}

Andreae, M. O., Jones, C. D., and Cox, P. M.: Strong present-day aerosol cooling implies a hot future, Nature, 435, 1187-1191, doi:10.1038/nature03671, 2005.

Arneth, A., Veenendaal, E. M., Best, C., Timmermans, W., Kolle, O., Montagnani, L., and Shibistova, O.: Water use strategies and ecosystem-atmosphere exchange of $\mathrm{CO}_{2}$ in two highly seasonal environments, Biogeosciences, 3, 421-437, doi:10.5194/bg-3421-2006, 2006.

Arneth, A., Miller, P. A., Scholze, M., Hickler, T., Schurgers, G., Smith, B., and Prentice, I. C.: $\mathrm{CO}_{2}$ inhibition of global terrestrial isoprene emissions: Potential implications for atmospheric chemistry, Geophys. Res. Lett., 34, L18813, doi:10.11029/12007GL030615, 2007.

Arneth, A., Schurgers, G., Hickler, T., and Miller, P. A.: Effects of species composition, land surface cover, $\mathrm{CO}_{2}$ concentration and climate on isoprene emissions from European forests, Plant Biol., 10, 150-162, doi:10.1055/s-2007-965247, 2008.

Arneth, A., Harrison, S. P., Zaehle, S., Tsigaridis, K., Menon, S., Bartlein, P. J., Feichter, J., Korhola, A., Kulmala, M., O’Donnell, D., Schurgers, G., Sorvari, S., and Vesala, T.: Terrestrial biogeochemical feedbacks in the climate system, Nat. Geosci, 3, 525532, doi:10.1038/ngeo1905, 2010a.

Arneth, A., Lehsten, V., Thonicke, K., and Spessa, A.: Climate-fire interactions and savanna ecosystems: a dynamic vegetation modelling study for the African continent, in: Ecosystem Function in Savannas: Measurement and Modeling at Landscape to Global Scales, edited by: Hill, M. J., and Hanan, N. P., Taylor \& Francis/CRC, Boca Raton, 2010b.

Arneth, A., Sitch, S., Bondeau, A., Butterbach-Bahl, K., Foster, P., Gedney, N., de Noblet-Ducoudré, N., Prentice, I. C., Sanderson, M., Thonicke, K., Wania, R., and Zaehle, S.: From biota to chemistry and climate: towards a comprehensive description of trace gas exchange between the biosphere and atmosphere, Biogeosciences, 7, 121-149, doi:10.5194/bg-7-121-2010, 2010c.

Arora, V. K. and Montenegro, A.: Small temperature benefits provided by realistic afforestation efforts, Nat. Geosci., 4, 514-518, doi:10.1038/ngeo1182, 2011.

Ashmore, M. R.: Assessing the future global impacts of ozone on vegetation, Plant Cell. Environ., 28, 949-964, 2005.

Atkin, O. K. and Tjoelker, M. G.: Thermal acclimation and the dynamic response of plant respiration to temperature, Trends Plant Sci., 8, 343-351, 2003.

Betts, R. A.: Offset of the potential carbon sink from boreal forestation by decreases in surface albedo, Nature, 408, 187-190, 2000.

Betts, R. A.: Biogeophysical impacts of land use on present-day climate: Near-surface temperature change and radiative forcing, Atmos. Sci. Lett., 2, 1-13, 2001.

Bond-Lamberty, B., Peckham, S. D., Ahl, D. E., and Gower, S. T.: Fire as the dominant driver of central Canadian boreal forest carbon balance, Nature, 450, 89-92, doi:10.1038/nature06272, 2007.

Bond, W. J., Woodward, F. I., and Midgley, G. F.: The global distribution of ecosystems in a world without fire, New Phytol., 165, 525-538, 2005.

Bonn, B. and Moortgat, G. K.: Sesquiterpene ozonolysis: Origin of atmospheric new particle formation from biogenic hydrocarbons, Geophys. Res. Lett., 30, 1585, doi:10.1029/2003GL017000, 2003.

Booth, B. B. B., Jones, C. D., Collins, M., Totterdell, I. J., Cox, P. M., Sitch, S., Huntingford, C., Betts, R., Harris, G. R., and Lloyd, J.: High sensitivity of future global warming to land carbon cycle uncertainties, Environ. Res. Lett., 7, doi:10.1088/17489326/7/2/024002, 2012.

Bowman, D. M. J. S., Balch, J. K., Artaxo, P., Bond, W. J., Carlson, J. M., Cochrane, M. A., D'Antonio, C. M., DeFries, R. S., Doyle, J. C., Harrison, S. P., Johnston, F. H., Keeley, J. E., Krawchuk, M. A., Kull, C. A., Marston, J. B., Moritz, M. A., Prentice, I. C., Roos, C. I., Scott, A. C., Swetnam, T. W., van der Werf, G. R., and Pyne, S. J.: Fire in the Earth System, Science, 324, 481-484, doi:10.1126/science.1163886, 2009.

Bucini, G. and Hanan, N. P.: A continental-scale analysis of tree cover in African savannas, Global Ecology and Biogeography, 16, 593-605, doi:10.1111/j.1466-8238.2007.00325.x, 2007. 
Canadell, J. G., Le Quéré, C., Raupach, M. R., Field, C. B., Buitenhuis, E. T., Ciais, P., Conway, T. J., Gillett, N. P., Houghton, R. A., and Marland, G.: Contributions to accelerating atmospheric $\mathrm{CO}_{2}$ growth from economic activity, carbon intensity, and efficiency of natural sinks, P. Natl. Acad. Sci., 104, 18866-18870, doi:10.1073/pnas.0702737104, 2007.

Carslaw, K. S., Boucher, O., Spracklen, D. V., Mann, G. W., Rae, J. G. L., Woodward, S., and Kulmala, M.: A review of natural aerosol interactions and feedbacks within the Earth system, Atmos. Chem. Phys., 10, 1701-1737, doi:10.5194/acp-10-17012010, 2010.

Challinor, A.: Agriculture: Forecasting food, Nature Clim. Change, 1, 103-104, 2011.

Clark, D. B., Mercado, L. M., Sitch, S., Jones, C. D., Gedney, N., Best, M. J., Pryor, M., Rooney, G. G., Essery, R. L. H., Blyth, E., Boucher, O., Harding, R. J., Huntingford, C., and Cox, P. M.: The Joint UK Land Environment Simulator (JULES), model description - Part 2: Carbon fluxes and vegetation dynamics, Geosci. Model Dev., 4, 701-722, doi:10.5194/gmd-4-701-2011, 2011.

Cramer, W., Bondeau, A., Woodward, F. I., Prentice, I. C., Betts, R. A., Brovkin, V., Cox, P. M., Fisher, V., Foley, J. A., Friend, A. D., Kucharik, C., Lomas, M., Ramankutty, N., Sitch, S., Smith, B., White, A., and Young-Molling, C.: Global response of terrestrial ecosystem structure and function to $\mathrm{CO}_{2}$ and climate change: results from six dynamic global vegetation models, Glob. Change Biol., 7, 357-373, 2001.

Crutzen, P. J., Mosier, A. R., Smith, K. A., and Winiwarter, W.: $\mathrm{N}_{2} \mathrm{O}$ release from agro-biofuel production negates global warming reduction by replacing fossil fuels, Atmos. Chem. Phys., 8, 389-395, doi:10.5194/acp-8-389-2008, 2008.

Dentener, F., Kinne, S., Bond, T., Boucher, O., Cofala, J., Generoso, S., Ginoux, P., Gong, S., Hoelzemann, J. J., Ito, A., Marelli, L., Penner, J. E., Putaud, J.-P., Textor, C., Schulz, M., van der Werf, G. R., and Wilson, J.: Emissions of primary aerosol and precursor gases in the years 2000 and 1750 prescribed data-sets for AeroCom, Atmos. Chem. Phys., 6, 4321-4344, doi:10.5194/acp-64321-2006, 2006a.

Dentener, F., Stevenson, D., Ellingsen, K., van Noije, T., Schultz, M., Amann, M., Atherton, C., Bell, N., Bergmann, D., Bey, I., Bouwman, L., Butler, T., Cofala, J., Collins, B., Drevet, J., Doherty, R., Eickhout, B., Eskes, H., Fiore, A., Gauss, M., Hauglustaine, D., Horowitz, L., Isaksen, I. S. A., Josse, B., Lawrence, M., Krol, M., Lamarque, J. F., Montanaro, V., Muller, J. F., Peuch, V. H., Pitari, G., Pyle, J., Rast, S., Rodriguez, J., Sanderson, M., Savage, N. H., Shindell, D., Strahan, S., Szopa, S., Sudo, K., Van Dingenen, R., Wild, O., and Zeng, G.: The global atmospheric environment for the next generation, Environ. Sci. Tech., 40, 3586-3594, 2006b.

de Noblet-Ducoudré, N., Boisier, J.-P., Pitman, A., Bonan, G. B., Brovkin, V., Cruz, F., Delire, C., Gayler, V., van den Hurk, B. J. J. M., Lawrence, P. J., van der Molen, M. K., Müller, C., Reick, C., Strengers, B. J., and Voldoire, A.: Determining robust impacts of land-use induced land-cover changes on surface climate over North America and Eurasia; Results from the first set of LUCID experiments, J. Climate, 25, 3261-3281, doi:10.1175/JCLID-11-00338.1, 2012.

Deryng, D., Sacks, W. J., Barford, C. C., and Ramankutty, N.: Simulating the effects of climate and agricultural management practices on global crop yield, Glob. Biogeochem. Cycles, 25,
GB2006, doi:10.1029/2009GB003765, 2011.

Donahue, N. M., Hartz, K. E. H., Chuong, B., Presto, A. A., Stanier, C. O., Rosenhorn, T., Robinson, A. L., and Pandis, S. N.: Critical factors determining the variation in SOA yields from terpene ozonolysis: A combined experimental and computational study, Faraday Disc., 130, 295-309, 2005.

Easterling, W. E., Aggarwal, P. K., Batima, P., Brander, K. M., Erda, L., Howden, S. M., Kirilenko, A., Morton, J., Soussana, J.-F., Schmidhuber, J., and Tubiello, F. N.: Food, fibre and forest products. in: Climate Change 2007: Impacts, Adaptation and Vulnerability, Contribution of Working Group II to the Fourth Assessment Report of the Intergovernmental Panel on Climate Change, edited by: Parry, M. L., Canziani, O. F., Palutikof, J. P., van der Linden, P. J., and Hanson, C. E., Cambridge, UK, 273-313, 2007. Friedlingstein, P., Cox, P., Betts, R., Bopp, L., Von Bloh, W., Brovkin, V., Cadule, P., Doney, S., Eby, M., Fung, I., Bala, G., John, J., Jones, C., Joos, F., Kato, T., Kawamiya, M., Knorr, W., Lindsay, K., Matthews, H. D., Raddatz, T., Rayner, P., Reick, C., Roeckner, E., Schnitzler, K. G., Schnur, R., Strassmann, K., Weaver, A. J., Yoshikawa, C., and Zeng, N.: Climate-carbon cycle feedback analysis: Results from the (CMIP)-M-4 model intercomparison, J. Climate, 19, 3337-3353, 2006.

Gornall, J., Betts, R., Burke, E., Clark, R., Camp, J., Willett, K., and Wiltshire, A.: Implications of climate change for agricultural productivity in the early twnty-first century, Phil. Trans. Royal Soc. B, 365, 2973-2989, doi:10.1098/rstb.2010.0158, 2010.

Gruber, N., and Galloway, J. N.: An Earth-system perspective of the global nitrogen cycle, Nature, 451, 293-296, 2008.

Gunderson, C. A., O’Hara, K. H., Campion, C. M., Walker, A. V., and Edwards, N. T.: Thermal plasticity of photosynthesis: the role of acclimation in forest responses to a warming climate, Glob. Change Biol., 16, 2272-2286, doi:10.1111/j.13652486.2009.02090.x, 2010.

Heald, C. L., Wilkinson, M. J., Monson, R. K., Alo, C. A., Wang, G. L., and Guenther, A.: Response of isoprene emission to ambient $\mathrm{CO}_{2}$ changes and implications for global budgets, Glob. Change Biol., 15, 1127-1140, doi:10.1111/j.1365-2486.2008.01802.x, 2009.

Hickler, T., Vohland, K., Feehan, J., Miller, P. A., Smith, B., Costa, L., Giesecke, T., Fronzek, S., Carter, T. R., Cramer, W., Kuhn, I., and Sykes, M. T.: Projecting the future distribution of European potential natural vegetation zones with a generalized, tree species-based dynamic vegetation model, Glob. Ecol. Biogeogr., 21, 50-63, doi:10.1111/j.1466-8238.2010.00613.x, 2012.

Higgins, S. I., Bond, W. J., and Trollope, W. S. W.: Fire, resprouting and variability: a recipe for grass-tree coexistence in savanna., J. Ecol., 88, 213-229, 2000.

Higgins, S. I. and Scheiter, S.: Atmospheric $\mathrm{CO}_{2}$ forces abrupt vegetation shifts locally, but not globally, Nature, advance online publication, doi:10.1038/nature11238, 2012.

Higgins, P.: Carbon cycle amplification: how optimistic assumptions cause persistent underestimates of potential climate damages and mitigation needs, Clim. Change, 95, 363-368, doi:10.1007/s10584-009-9607-1, 2009.

Hikosaka, K., Ishikawa, K., Borjigidai, A., Muller, O., and Onoda, Y.: Temperature acclimation of photosynthesis: mechanisms involved in the changes in temperature dependence of photosynthetic rate, J. Exp. Bot., 57, 291-302, doi:10.1093/jxb/erj049, 2006. 
Hoffmann, W. A., Orthen, B., and Nascimento, P. K. V. d.: Comparative fire ecology of tropical savanna and forest trees, Funct. Ecol., 17, 720-726, 2003.

Houghton, R. A.: Revised estimates of the annual flux of carbon to the atmosphere from changes in land use and land management 1850-2000, Tellus, 55, 378-390, 2003.

Huang, Y., Yu, Y., Zhang, W., Sun, W., Liu, S., Jiang, J., Wu, J., Yu, W., Wang, Y., and Yang, Z.: Agro-C: A biogeophysical model for simulating the carbon budget of agroecosystems, Ag. For. Met., 149, 106-129, doi:10.1016/j.agrformet.2008.07.013, 2009.

Huntingford, C., Booth, B. B. B., Sitch, S., Gedney, N., Lowe, J. A., Liddicoat, S. K., Mercado, L. M., Best, M. J., Weedon, G. P., Fisher, R. A., Lomas, M. R., Good, P., Zelazowski, P., Everitt, A. C., Spessa, A. C., and Jones, C. D.: IMOGEN: an intermediate complexity model to evaluate terrestrial impacts of a changing climate, Geosci. Model Dev., 3, 679-687, doi:10.5194/gmd-3679-2010, 2010.

Hulme, M.: Meet the humanities, Nature Clim. Change, 1, 177-179, 2011

Isbell, F., Calcagno, V., Hector, A., Connolly, J., Harpole, W. S., Reich, P. B., Scherer-Lorenzen, M., Schmid, B., Tilman, D., van Ruijven, J., Weigelt, A., Wilsey, B. J., Zavaleta, E. S., and Loreau, M.: High plant diversity is needed to maintain ecosystem services, Nature, 477, 199-202, doi:10.1038/nature10282, 2011.

Ito, A., Sudo, K., Akimoto, H., Sillman, S., and Penner, J.: Global modeling analysis of tropospheric ozone and its radiative forcing from biomass burning emissions in the twentieth century, J. Geophys. Res., 112, D24307, doi:10.1029/2007JD008745, 2007.

Jaggard, K. W., Aiming, Q., and Ober, E. S.: Possible changes to arable crop yields by 2010, Philos. Trans. R. Soc. B, 365, 28352851, doi:10.1098/rstb.2010.0153, 2010.

Janhäll, S., Andreae, M. O., and Pöschl, U.: Biomass burning aerosol emissions from vegetation fires: particle number and mass emission factors and size distributions, Atmos. Chem. Phys., 10, 1427-1439, doi:10.5194/acp-10-1427-2010, 2010.

Kattge, J. and Knorr, W.: Temperature acclimation in a biochemical model of photosynthesis: a reanalysis of data from 36 species, Plant Cell Environ., 30, 1176-1190, 10.1111/j.13653040.2007.01690.x, 2007.

Kattge, J., DÍAz, S., Lavorel, S., Prentice, I. C., Leadley, P., BÖNisch, G., Garnier, E., Westoby, M., Reich, P. B., Wright, I. J., Cornelissen, J. H. C., Violle, C., Harrison, S. P., van Bodegom, P. M., Reichstein, M., Enquist, B. J., Soudzilovskaia, N. A., Ackerly, D. D., Anand, M., Atkin, O., Bahn, M., Baker, T. R., Baldocchi, D., Bekker, R., Blanco, C. C., Blonder, B., Bond, W. J., Bradstock, R., Bunker, D. E., Casanoves, F., CavenderBares, J., Chambers, J. Q., Chapin, F. S., Chave, J., Coomes, D., Cornwell, W. K., Craine, J. M., Dobrin, B. H., Duarte, L., Durka, W., Elser, J., Esser, G., Estiarte, M., Fagan, W. F., Fang, J., Fernandez-Mendez, F., Fidelis, A., Finegan, B., Flores, O., Ford, H., Frank, D., Freschet, G. T., Fyllas, N. M., Gallagher, R. V., Green, W. A., Gutierrez, A. G., Hickler, T., Higgins, S., Hodgson, J. G., Jalili, A., Jansen, S., Joly, C., Kerkhoff, A. J., Kirkup, D. O. N., Kitajima, K., Kleyer, M., Klotz, S., Knops, J. M. H., Kramer, K., KÜHn, I., Kurokawa, H., Laughlin, D., Lee, T. D., Leishman, M., Lens, F., Lenz, T., Lewis, S. L., Lloyd, J. O. N., LlusiÀ, J., Louault, F., Ma, S., Mahecha, M. D., Manning, P., Massad, T., Medlyn, B., Messier, J., Moles, A. T., MÜLler, S. C., Nadrowski, K., Naeem, S., Niinemets, Ü., Nöllert, S., Nüske, A.,
Ogaya, R., Oleksyn, J., Onipchenko, V. G., Onoda, Y., OrdoÑEz, J., Overbeck, G., Ozinga, W. A., Patino, S., Paula, S., Pausas, J. G., Penuelas, J., Phillips, O. L., Pillar, V., Poorter, H., Poorter, L., Poschlod, P., Prinzing, A., Proulx, R., Rammig, A., Reinsch, S., Reu, B., Sack, L., Salgado-Negret, B., Sardans, J., Shiodera, S., Shipley, B., Siefert, A., Sosinski, E., Soussana, J.-F., Swaine, E., Swenson, N., Thompson, K. E. N., Thornton, P., Waldram, M., Weiher, E., White, M., White, S., Wright, S. J., Yguel, B., Zaehle, S., Zanne, A. E., and Wirth, C.: TRY - a global database of plant traits, Glob. Change Biol., 17, 2905-2935, doi:10.1111/j.13652486.2011.02451.x, 2011.

Kleinen, T., Tarasov, P., Brovkin, V., Andreev, A., and Stebich, M.: Comparison of modeled and reconstructed changes in forest cover through the past 8000 years: Eurasian perspective, Holocene, 21, 723-734, doi:10.1177/0959683610386980, 2011.

Knorr, W., and Kattge, J.: Inversion of terrestrial ecosystem model parameter values against eddy covariance measurements by Monte Carlo sampling, Glob. Change Biol., 11, 1333-1351, 2005.

Kozlowski, T. T., and Pallardy, S. G.: Acclimation and adaptive responses of woody plants to environmental stresses, Botanical Review, 68, 270-334, 2002.

Kühn, I., Böhning-Gaese, K., Cramer, W., and Klotz, S.: Macroecology meets global change research, Global Ecol. Biogeo., 17, 3-4, doi:10.1111/j.1466-8238.2007.00377.x, 2008.

Kulmala, M.: How particles nucleate and grow, Science, 302, 1000 1001, 2003.

Kulmala, M., Suni, T., Lehtinen, K. E. J., Dal Maso, M., Boy, M., Reissell, A., Rannik, Ü., Aalto, P., Keronen, P., Hakola, H., Bäck, J., Hoffmann, T., Vesala, T., and Hari, P.: A new feedback mechanism linking forests, aerosols, and climate, Atmos. Chem. Phys., 4, 557-562, doi:10.5194/acp-4-557-2004, 2004.

Lamarque, J.-F., Bond, T. C., Eyring, V., Granier, C., Heil, A., Klimont, Z., Lee, D., Liousse, C., Mieville, A., Owen, B., Schultz, M. G., Shindell, D., Smith, S. J., Stehfest, E., Van Aardenne, J., Cooper, O. R., Kainuma, M., Mahowald, N., McConnell, J. R., Naik, V., Riahi, K., and van Vuuren, D. P.: Historical (1850-2000) gridded anthropogenic and biomass burning emissions of reactive gases and aerosols: methodology and application, Atmos. Chem. Phys., 10, 7017-7039, doi:10.5194/acp10-7017-2010, 2010.

Langmann, B., Duncan, B., Textor, C., Trentmann, J., and van der Werf, G. R.: Vegetation fire emissions and their impact on air pollution and climate, Atmos. Env., 43, 107-116, doi:10.1016/j.atmosenv.2008.09.047, 2009.

Levis, S.: Modelling vegetation and land use change in models of the Earth System, WIREs Climate Change, 1, 840-856, doi:10.1002/wcc.1083, 2010.

Lisboa, C. C., Butterbach-Bahl, K., Mauder, M., and Kiese, R.: Bioethanol production from sugarcane and emissions of greenhouse gases - known and unknowns, GCB Bioenergy, 3, 277 292, doi:10.1111/j.1757-1707.2011.01095.x, 2011.

Litton, C. M., Raich, J. W., and Ryan, M. G.: Review: Carbon Allocation in Forest Ecosystems, Glob. Change Biol., 13, 2089-2109; doi:10.1111/j.1365-2486.2007.01420.x, 2007.

Liu, L., and Greaver, T. L.: A review of nitrogen enrichment effects on three biogenic GHGs: the $\mathrm{CO}_{2}$ sink may be largely offset by stimulated $\mathrm{N}_{2} \mathrm{O}$ and $\mathrm{CH}_{4}$ emission, Ecol. Lett., 12, 1103-1117, 2009. 
Lloyd, J., Shibistova, O., Zolotoukhine, D., Kolle, O., Arneth, A., Wirth, C., Styles, J. M., Tchebakova, N. M., and Schulze, E. D.: Seasonal and annual variations in the photosynthetic productivity and carbon balance of a central Siberian pine forest, Tellus, 54, 590-610, 2002.

Lohmann, U. and Feichter, J.: Global indirect aerosol effects: a review, Atmos. Chem. Phys., 5, 715-737, doi:10.5194/acp-5-7152005, 2005.

Makkonen, R., Asmi, A., Kerminen, V.-M., Boy, M., Arneth, A., Hari, P., and Kulmala, M.: Air pollution control and decreasing new particle formation lead to strong climate warming, Atmos. Chem. Phys., 12, 1515-1524, doi:10.5194/acp-12-15152012, 2012.

Marlon, J. R., Bartlein, P. J., Carcaillet, C., Gavin, D. G., Harrison, S. P., Higuera, P. E., Joos, F., Power, M. J., and Prentice, I. C.: Climate and human influences on global biomass burning over the past two millennia, Nat. Geosci., 1, 697-702, 2008.

Medlyn, B. E., Dreyer, E., Ellsworth, D., Forstreuter, M., Harley, P. C., Kirschbaum, M. U. F., Roux, X. L., Montpied, P., Strassemeyer, J., Walcroft, A., Wang, K., and Loustau, D.: Temperature response of parameters of a biochemically based model of photosynthesis. II. A review of experimental data, Plant Cell Environ., 25, 1167-1179, 2002.

Melillo, J. M., Reilly, J. M., Kicklighter, D. W., Gurgel, A. C., Cronin, T. W., Paltsev, S., Felzer, B. S., Wang, X., Sokolov, A. P., and Schlosser, C. A.: Indirect Emissions from Biofuels: How Important?, Science, doi:10.1126/science.1180251, 2009.

Mieville, A., Granier, C., Liousse, C., Guillaume, B., Mouillot, F., Lamarque, J. F., Grégoire, J. M., and Pétron, G.: Emissions of gases and particles from biomass burning during the 20th century using satellite data and an historical reconstruction, Atmos. Env., 44, 1469-1477, doi:10.1016/j.atmosenv.2010.01.011, 2010.

Miller, P. A., Giesecke, T., Hickler, T., Bradshaw, R. H. W., Smith, B., Seppä, H., and Sykes, M. T.: Exploring climatic and biotic controls on Holocene vegetation change in Fennoscandia, J. Ecol., 247-259, doi:210.1111/j.1365-2745.2007.01342.x, 2008.

Mueller, C., Bondeau, A., Popp, A., Waha, K., and Fader, M.: Climate change impacts on agricultural yields. Background note to the World Development Report, The World Bank, 2010.

Ng, N. L., Chhabra, P. S., Chan, A. W. H., Surratt, J. D., Kroll, J. H., Kwan, A. J., McCabe, D. C., Wennberg, P. O., Sorooshian, A., Murphy, S. M., Dalleska, N. F., Flagan, R. C., and Seinfeld, J. H.: Effect of $\mathrm{NO}_{\mathrm{x}}$ level on secondary organic aerosol (SOA) formation from the photooxidation of terpenes, Atmos. Chem. Phys., 7, 5159-5174, doi:10.5194/acp-7-5159-2007, 2007.

Niinemets, Ü., Monson, R. K., Arneth, A., Ciccioli, P., Kesselmeier, J., Kuhn, U., Noe, S. M., Peñuelas, J., and Staudt, M.: The leaflevel emission factor of volatile isoprenoids: caveats, model algorithms, response shapes and scaling, Biogeosciences, 7, 18091832, doi:10.5194/bg-7-1809-2010, 2010.

Pechony, O. and Shindell, D. T.: Fire parameterization on a global scale, J. Geophys. Res., 114, doi:10.1029/2009jd011927, 2009.

Pechony, O., and Shindell, D. T.: Driving forces of global wildfires over the past millennium and the forthcoming century, P. Natl. A. Sci., 107, 19167-19170, doi:10.1073/pnas.1003669107, 2010.

Pitman, A., Arneth, A., and Ganzeveld, L.: Regionalizing global climate models, Int. J. Climatol., doi:10.1002/joc.2279., 2011.
Pitman, A. J., de Noblet-Ducoudré, N., Cruz, F. T., Davin, E. L., Bonan, G. B., Brovkin, V., Claussen, M., Delire, C., Ganzeveld, L., Gayler, V., van den Hurk, B. J. J. M., Lawrence, P. J., van der Molen, M. K., Müller, C., Reick, C. H., Seneviratne, S. I., Strengers, B. J., and Voldoire, A.: Uncertainties in climate responses to past land cover change: First results from the LUCID intercomparison study, Geophys. Res. Lett., 36, doi:10.1029/2009g1039076, 2009.

Possell, M. and Hewitt, C. N.: Isoprene emissions from plants are mediated by atmospheric $\mathrm{CO}_{2}$ concentrations, Glob. Change Biol., 17, 1595-1610, doi:10.1111/j.1365-2486.2010.02306.x, 2010.

Prentice, I. C.: The Burning Issue, Science, 330, 1636-1637, doi"10.1126/science.1199809, 2010.

Raes, F., Liao, H., Chen, W.-T., and Seinfeld, J. H.: Atmospheric chemistry-climate feedbacks, J. Geophys. Res., 115, D12121, doi:10.1029/2009jd013300, 2010.

Rotter, R. P., Carter, T. R., Olesen, J. E., and Porter, J. R.: Cropclimate models need an overhaul, Nature Clim. Change, 1, 175177, doi:10.1038/nclimate1152, 2011.

Rounsevell, M. D. A. and Arneth, A.: Representing human behaviour and decisional processes in land system models as an integral component of the earth system, Glob. Env. Change, 21, 840-843, 2011.

Schaphoff, S., Lucht, W., Gerten, D., Sitch, S., Cramer, W., and Prentice, I. C.: Terrestrial biosphere carbon storage under alternative climate projections, Clim. Change, 74, 97-122, 2006.

Scheffer, M., Holmgren, M., Brovkin, V., and Claussen, M.: Synergy between small- and large-scale feedbacks of vegetation on the water cycle, Glob. Change Biol., 11, 1003-1012, 2005.

Scheiter, S. and Higgins, S. I.: Impacts of climate change on the vegetation of Africa: an adaptive dynamic vegetation modelling approach (aDGVM), Glob. Change Biol., 15, 2224-2246, doi:2210.1111/j.1365-2486.2008.01838.x, 2009.

Scholze, M., Knorr, W., Arnell, N., and Prentice, I. C.: A climate change risk analysis for world ecosystems, Proc. Nat. Acad. Sci. USA, 103, 13116-13120, doi:10.11073/pnas.0601816103, 2006.

Scholze, M., Kaminski, T., Rayner, P., Knorr, W., and Giering, R.: Propagating uncertainty through prognostic CCDAS simulations, J. Geophys. Res., 112, D17305, doi:10.1029/2007JD008642, 2007.

Smith, B., Prentice, I. C., and Sykes, M. T.: Representation of vegetation dynamics in the modelling of terrestrial ecosystems: comparing two contrasting approaches within European climate space, Glob. Ecol. Biogeo., 10, 621-637, 2001.

Soden, B. J. and Held, I. M.: An assessment of climate feedbacks in coupled ocean-atmosphere models, J. Climate, 19, 3354-3360, doi:10.1175/JCLI3799.1, 2006.

Solomon, A. M. and Kirilenko, A. P.: Climate change and terrestrial biomass: What if trees do not migrate?, Glob. Ecol. Biogeo. Lett., 6, 139-148, 1997.

Staver, A. C., Archibald, S., and Levin, S. A.: The Global Extent and Determinants of Savanna and Forest as Alternative Biome States, Science, 334, 230-232, doi:10.1126/science.1210465, 2011.

Trnka, M., Olesen, J. E., Kersebaum, K. C., SkjelvÅG, A. O., Eitzinger, J., Seguin, B., Peltonen-Sainio, P., Rötter, R., Iglesias, A. N. A., Orlandini, S., DubrovskÝ, M., Hlavinka, P., Balek, J., Eckersten, H., Cloppet, E., Calanca, P., Gobin, A., Vučetic, V., Nejedlik, P., Kumar, S., Lalic, B., Mestre, A., Rossi, F., Kozyra, 
J., Alexandrov, V., SemerÁDovÁ, D., and ŽAlud, Z.: Agroclimatic conditions in Europe under climate change, Glob. Change Biol., 17, 2298-2318, doi:10.1111/j.1365-2486.2011.02396.x, 2011.

Van Groenigen, K. J., Osenberg, C. W., and Hungate, B. A.: Increased soil emissions of potent greemnhouse gases under increased atmospheric $\mathrm{CO}_{2}$, Nature, 475, 214-U121, doi:101038/nature110176, 2011.

Van Minnen, J. G., Leemans, R., and Ihle, F.: Defining the importance of including transient ecosystem responses to simulate Ccycle dynamics in a global change model, Glob. Change Biol., 6, 595-611, doi:10.1046/j.1365-2486.2000.00323.x, 2000.

Wang, Z., Chappellaz, J., Park, K., and Mak, J. E.: Large variations in Southern Hemisphere biomass burning during the last 650 Years, Science, 330, 1663-1666, doi:10.1126/science.1197257, 2010.

Wania, R., Ross, I., and Prentice, I. C.: Implementation and evaluation of a new methane model within a dynamic global vegetation model: LPJ-WHyMe v1.3.1, Geosci. Model Dev., 3, 565-584, doi:10.5194/gmd-3-565-2010, 2010.
Wolf, A., Ciais, P., Bellassen, V., Delbart, N., Field, C. B., and Berry, J. A.: Forest biomass allometry in global land surface models, Glob. Biogeochem. Cycles, 25, GB3015, doi:10.1029/2010gb003917, 2011.

Wolf, B., Zheng, X. H., Brueggemann, N., Chen, W. W., Dannenmann, M., Han, X. G., Sutton, M. A., Wu, H. H., Yao, Z. S., and Butterbach-Bahl, K.: Grazing-induced reduction of natural nitrous oxide release from continental steppe, Nature, 464, 881884, doi:10.1038/nature08931, 2010.

Zaehle, S., Sitch, S., Smith, B., and Hatterman, F.: Effects of parameter uncertainties on the modeling of terrestrial biosphere dynamics, Glob. Biogeochem. Cycles, 19, GB3020, doi:10.1029/2004GB002395, 2005.

Zaehle, S. and Friend, A. D.: Carbon-nitrogen cycle dynamics in the ORCHIDEE-CN land surface model: Part 1: Model evaluation and sensitivity, Global Biogeochem. Cycles, 24, GB1005, 2010.

Zaehle, S., Ciais, P., Friend, A. D., and Prieur, V.: Carbon benefits of anthropogenic reactive nitrogen offset by nitrous oxide emissions, Nat. Geosci., 4, 601-605, doi:10.1038/NGEO1207, 2011.

Ziehn, T., Kattge, J., Knorr, W., and Scholze, M.: Improving the predictability of global $\mathrm{CO}_{2}$ assimilation rates under climate change, Geophys. Res. Lett., 38, L10404, doi:10.1029/2011g1047182, 2011. 